\title{
A NEW FROG FROIM PUERTO RICO
}

\author{
Chapman Grant, Major, United States Army.
}

My collection of over 6,000 specimens collected in nineteen months in and near Puerto Rico contains 21 species or subspecies and one renus not listed in the last herpetology of this Island. The present is the most elusive species discovered. It may be called:

\section{Eleutherodactylus cooki sp. nov.}

Type-From Pandura Mountains, Southeastern Puerto Rico, eollected by Chapman Grant, January 24, 1932. Chapman Grant collection. No. 4108 , adult.

Range-Known only from type locality.

Diagniosis-Distinguished from the other salentia of Puerto Rico by having vent to heel as long as vent to snout; toe dises twice as wide as long and plain brown back. Thighs and venter only slightly and finely rugose. Eyes very large. Throat sometimes canary yellow. Voice distinct. Life history distinct.

Description of type-Habitus slender, head wider than body, eyes large and protruding; limbs weak, relatively long, heels widely overlapping when thighs are placed at right angles to body; heel reaches snout when extended forward. Vomerine teeth in slightly curved oblique series, behind and within the choanae, the distance between series about half the length of one series. Tongue large, oval, notched behind. Nostrils near tip of snout, prominent. Tympanum distinet, its width slightly less than half the width of eye.

Eye very large, width equal to eye to tip of snout, appears black but when a living specimen is examined in sunlight the iris is black, finely reticulated with gold. The edge of the eyelid is white, making a narrow white line around the eye. The eye protrudes so far that the impression of mouse ears is given. Unfortunately, the eyes shrink somewhat in alcohol. The four fingers free with dises twice as wide as long; tubercles prominent, the five toes free with similar dises. Skin smooth below except for slightly rugose venter, lower surface of thighs slightly rugose; above smooth except for a few scattered excrescences or warts. Color in life, light brown above, darker at head, legs lighter, underside nearly white, but minutely and evenly specked with dark. No markings.

Measurements-Snout to vent $37 \mathrm{~mm}$; vent to heel $37 \mathrm{~mm}$; width 
of head $15 \mathrm{~mm}$; snout to posterior edge of tympanum $14 \mathrm{~mm}$; leg from vent $60 \mathrm{~mm}$.; foreleg from axilla $26 \mathrm{~mm}$.; tibia $18 \mathrm{~mm}$; hind foot $23 \mathrm{~mm}$.

Voice-Four more specimens were taken alive February 28th and fourteen more on March 27th. They were lrept separate to hear a "pure culture" vocalization. L. richmondi oceurs in small numbers in the same locality, so it was thought important to check positively on the song. The four specimens were kept separate over night and sang. There is not the slightest resemblance to the voice of any of the other Eleutherodactyls of Puerto Rico. One adult was seen in the act of singing. The body was raised on front feet at a forty-five degree angle, hindquarters on a boulder, throat distended and vibrating. The note is repeated six or seven times and cannot be reproduced by a syllable or on the piano. The nearest is pe-pe-pe-pe-pe-pe pe, onesixteenth notes in second $A$ treble. The note has a liquid sound and can best be imitated by whistling.

On March 27, fourteen specimens were taken. Although the weather conditions were similar to February 28 th as to dryness, the temperature was probably slightly higher. The amount of singing had greatly increased, probably due to breeding. More frogs were seen in the "open", i.e., on the perpendicular faces of the rocks, and fewer hidden in cracks. The yellow throats prodominated. Probably they were the males, singing and in search of females.

Aside from an entirely clifferent voice, this species differs from E. portoricensis in the following details:

\section{E. portoricensis}

Heel to vent

less than vent to snout

Rugosity of belly coarso and thighs

Digit pads

Width of ear Width of eye

Iris

Back

Throat

Habitat

Song

Underside slightly wider than long over half width of eye less than eye to snout. Appears normal.

lighter above punil. Brassy variously colored or marked never bright yellow above ground co-qui' (accented) dark
E. cooki

equal or longer than vent to snout

fine

over twice as wide as long less than half width of eye equals eye to snout. So large as to resemble mouse ears.

all same color, appearing black one color, no markings sometimes bright yellow deep caves pe-pe-pe-pe-pe-(melodious) nearly white 


\section{Life history:}

An eyed egg is $6 \mathrm{~mm}$. in diameter; uneyed, from $4 \mathrm{~mm}$. up. They are covered with a thin layer of viscous gelatin and pasted together in a single layer in a clump of about twenty-five on the perpendicular face of a damp rough boulder in the semi-darkness of the chasms. When lifting the eggs from the granite, by getting hold of two or three, the whole elutch may peel off as a unit. At each clutch seen, a frog was sitting next to the eggs, facing away from them.

Two clutches of $E$. cooki eggs were allowed to hateh in a vial containing a rag kept wet for moisture. A similar vial contained $E$. portoricensis eggs. Upon hatehing, E. portoricensis measured 6 $\mathrm{mm}$. snout to vent and $E$. cooki measured sver $8 \mathrm{~mm}$. Newly hatched $E$. portoricensis is dark brown with seattered white dots, larger and fewer above and numerous and small below. Newly hatched $E$. cooli is much larger, light olive with complieated dorsal markings of darker brown; rings around fore and hind legs, wide band joining eyes, ete.

Variation: About half of the specimens have canary yellow on the throat, some have solid yellow or yellow blotches, the others light fbrown. Unfortunately, the yellow fades in twelve hours in alcohol. In smaller specimens, the yellow is in patches. On large specimens, the throat and extending back to just behind the front legs is a clear canary yellow. The only sign of pattern above is a faint light band joining the eyes, seen only at certain imes. Some of the largest males (?) have yellow on the sides, where the thighs usually cover, and yellow tinges on the thighs. The white ring around the eye is very noticeable in living specimens. The eye is black and gold and the same color above as below the horizontal pupil. The nictitating membrane closes from the rear forward and completely covers the eye at will.

Remarks-There was an infestation of small red ticks on the legs and sides of these frogs.

This is the most romantic species on the Island. It inhabits the "guajonales" 'of the Pandura Mountains, and is known locally as a "guajone". A "guajonal" is a place where wild bamboo grows, but here used to designate a mountain gorge tumbled full of granite boulders from bungalow to grand piano size. One can hear from the surface a most melodious note coming from the depths, a sweet liquid pe-pe-pe-pe-pe-pe-pe resounds from the gloomy caves, echoes, re-echoes and is repeated by other "guajones". "The 'guajone' is only a voice. No one has ever seen one", the natives say. In the day time, with 
a flash light, one can crawl down one, two, three tiers of jumbled boulders to the hidden stream bed in disintegrating granite. The "guajones" sing, but it is impossible to locate them by ear. The flashlight and a slender twig will serve to locate and dislodge them from deep cracks less than half an inch wide under the husks of exfoliating granite, or from the damp earth where earth and boulder meet. It took me three all-day trips to secure one specimen. It was only on the third trip that I discovered their hiding places and then several escaped after being pried out. One might as well try to bribe a mountaineer to eatch a ghost as a "guajone". I tried it; money is no object.

The frog is a poor swimmer. It does not go into water of its own accord. When placed in water, it gets out as quickly as it can. Its movements in water are in contrast to its agility on boulders.

Specimens taken-19.

Named in honor of Dr. Melville T. Cook

Note: Since going to press the number of specimens taken has increased to 66 ; some measuring as much as $54 \mathrm{~mm}$. snout to vent. 